Journal of Social Sciences 5 (4): 381-385, 2009

ISSN 1549-3652

(C) 2009 Science Publications

\title{
Factors Influencing Mathematic Problem-Solving Ability of Sixth Grade Students
}

\author{
${ }^{1}$ Sakorn Pimta, ${ }^{2}$ Sombat Tayruakham and ${ }^{3}$ Prasart Nuangchalerm \\ ${ }^{1}$ Chumchonbanchomsa-Ard School, Moeiwadi District, \\ Roi-et Province 45250 Thailand \\ ${ }^{2}$ Department of Research and Development Education, Faculty of Education, \\ Mahasarakham University, Mahasarakham 44000 Thailand \\ ${ }^{3}$ Department of Curriculum and Instruction, Faculty of Education, \\ Mahasarakham University, Mahasarakham 44000 Thailand
}

\begin{abstract}
Problem statement: This study aims to investigate factors influencing mathematic problem-solving ability of sixth grade students. One thousand and twenty eight of sixth grade students, studying in the second semester of academic year 2007 were sampled by stratified random sampling technique. Approach: The research instruments used in the study included mathematic problemsolving ability test and questionnaires. Data was analyzed by Path Analysis. Results: Factors influencing mathematic problem-solving ability were represented as following: (1) direct factors influencing mathematic problem-solving ability were described that direct and indirect factors influencing mathematic problem-solving ability were attitude towards mathematics, self-esteem and teachers' teaching behavior. Indirect factors influencing mathematic problem-solving ability were motivation and self-efficacy (2) factor models influencing mathematic problem-solving ability of sixth grade students was associated with visual data (3) The developed model could describe variance of skill in mathematic problem-solving at $63.00 \%\left(\mathrm{R}^{2}=0.63\right)$. Conclusion: Teacher's behaviors took both direct and indirect effects on the students' mathematic problem solving. The teachers are supposed to study the methods to develop this ability deeply and then bring them to manage the activities in class that encourage students to be enthusiastic to learn and have good attitude toward mathematic learning or to get students' concentration.
\end{abstract}

Key words: Mathematics, problem-solving, attention, attitude, motivation, self-esteem, self-efficacy, teaching behavior

\section{INTRODUCTION}

Mathematical problem is the tool used as not only to help students develop their thinking ability but it also helps them to develop their basic skills of solving the problems especially a problem in daily life. The goal of teaching mathematic to be effective was that the students were able to solve its problems. As a matter of fact, the experience in solving the problems of the subject is very important to develop students' thinking skills and help them gain more skills in solving the problem in daily life $\mathrm{e}^{[1,2]}$.

Problem-solving is considered as the heart of mathematic learning because the skill is not only for learning the subject but it emphasizes on developing thinking skill method as well. Students can apply their knowledge and problem solving skills to be useful in daily life since the processes of solving the mathematic problem are similar to the general problem solving ${ }^{[3]}$.

Basic education curriculum, Buddhist era 2544 has specified how mathematic learning and students' quality are important; however, the students do not achieve in learning the subject. Most of the students' problem was the mathematical problem solving, the important skill for the students' further learning. Therefore, the development of problem solving in mathematics is an important mission that teachers are about to concern with in order to develop such the necessary skill for their students ${ }^{[4-6]}$.

According to the study of the educators and psychologists, students will have an effective problem solving skill or not depends on Bloom's learning theory $^{[7]}$ revealed that there were three factors influencing on students' learning achievement

Corresponding Author: Sombat Tayraukham, Department of Research and Development Education, Faculty of Education, Mahasarakham University, Mahasarakham 44000 Thailand 
including, cognitive domain namely students' own background knowledge and skills, effective domain such as attitude on the subject, school and learning processes, interest, motivation, self-efficacy, selfesteem and teaching quality factors namely, instruction acknowledgement, participation in class activities, teacher's sanction system and giving feedbacks. Also, achievement motive theory ${ }^{[8]}$ focuses on achievement motive rather than any other factors because he thought that it is the most important key for students to succeed in their study. Any student who has high achievement motive will have high concentration in learning and he will be then successful in his study; on the other hand, if one has low achievement motive, he will lack of concentration and he will not achieve in his study at the result.

Social cognitive theory ${ }^{[9]}$ revealed that self-efficacy is the base of motivation. Any one who acknowledges his ability and also has high goal will have better motivation to work or learn and trend to be more successful in his life than one who is still doubtful with his ability. According to the problem of mathematic teaching and learning and due to the theory studies, we have found out that the study of factors affecting the students' problem solving is interesting and necessary because if teachers know about the factors that encourage or obstruct students' problem solving skill development, they can then manage effective learning activities for the students in order to help them solve mathematic problems effectively.

Therefore, the researchers are interested in study the effective domain factors influencing mathematic problem-solving of sixth grade students. This study aims to study factors influencing mathematic problemsolving of sixth grade students and to develop and inspect the accuracy of factor models that influence mathematic problem-solving of sixth grade students.

\section{MATERIALS AND METHODS}

Participants: The population of this research comprised of sixth grade students attending the second semester of academic year 2008 in Roi-et educational service area 3 . There were 4,972 students from 205 schools. One thousand and twenty eight students attending the second semester of academic year 2008 were sampled by stratified random sampling.

Variables: Independent variables of the research were concentration, attitude towards mathematics, achievement motive, self-esteem and teacher's behaviors.

Dependent variable used for the research was, problem solving ability.

\section{Research tools:}

- One set of the problem-solving test. It was a fourchoice test including 30 items. The test's difficulty value was between 0.24 and 0.80 , its discrimination power ranged between 0.20 and 0.48 and the reliability of this test was 0.86

- Two evaluation forms including, factor influencing students' mathematics problem-solving abilities evaluation form and 5-level rating scale divided into 6 section as follows:

- Section 1 twelve concentration evaluation forms, the discrimination was between 0.190.74 and the reliability of it was. 84

- Section 2 twelve-item attitude on mathematics evaluation form which had its discrimination power as $0.21-0.52$ and the reliability was 77

- Section 3 twelve-item achievement motive evaluation form which included 0.26-0.64 as its discrimination power and the reliability of it was 0.83

- Section 4 sixteen-item self-esteem evaluation form which had $0.18-0.60$ as its discrimination power and the reliability of it was 0.83

- Section 5 ten-item of self-evaluation from, the discrimination power was between 0.49-0.60 and its reliability was 0.85

- Section 6 twelve-item teacher's behavior evaluation form, the discrimination of it was between $0.32-0.71$ and its reliability was 0.86

Data collection: Data were collected in February, 2008, conduct a testing with sample group by mathematics problem-solving test that the researchers had made and test what factors influencing their problem-solving abilities by an evaluation form that the researchers made. After collecting the data from all of the sample schools, check the data to be ready for further analysis.

Data analysis: Analysis of the basic statistics of the educational variables including, mean, standard deviation and multi-relation coefficient between the variables by instant computerized program. Analysis of concealed and visible variables' assured component of this research. Then, analyze inspecting the research hypothesis by path analysis.

\section{RESULTS}

- The factors influencing mathematic problemsolving of sixth grade students (Fig. 1) were:

- The factor that influence mathematic problemsolving of sixth grade students was concentration on study 


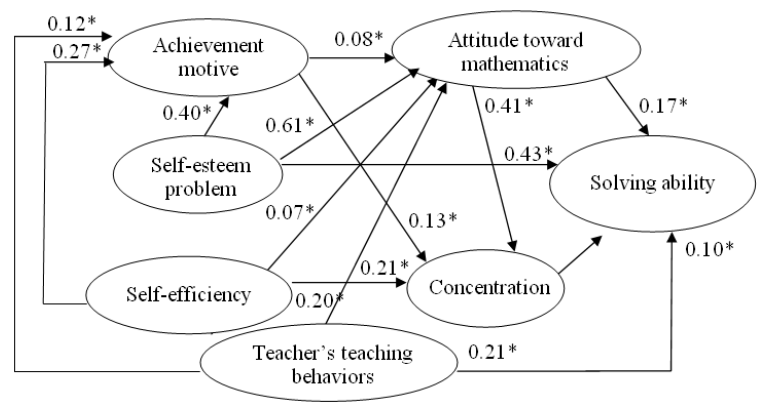

Fig. 1: Casual factor models influencing mathematics problem-solving

- The factors that held both direct and indirect effect on the student's solving problem were attitude to ward the subject, self-esteem and teacher's behavior

- The factors that took only indirect effect on the students' problem solving were achievement motive and self-efficacy

- Factor models influence mathematic problemsolving of sixth grade students was associated with visual data $\left(\chi^{2}=58.91, \quad \mathrm{df}=46, \mathrm{p}=0.096\right)$ $\mathrm{GFI}=1.00, \mathrm{AGFI}=0.97, \mathrm{RMR}=0.082$

- The developed model could describe variance of skills in mathematics problem-solving at $63.00 \%$ $\left(\mathrm{R}^{2}=0.63\right)$

\section{DISCUSSION}

The developed models could explain the variance of the problem-solving ability at $63.00 \%$ which was the effect of effective domain, while $37.00 \%$ was for other factors that were not involved in the research. If another factor such as a cognitive was involved in the research analysis, the models might have more effective explanation.

The models influencing mathematic problemsolving of sixth grade students were as follows:

- Concentration was the positive direct effect on mathematic problem solving at 0.01 level of significance. This meant the students had high concentration on studying and the teacher taught effectively, thus they could understand. In this case, if the students understand the lesson well, they will know the methods of solving the problems, then they will achieve in their study. If students have concentration in learning, their learning achievement will be absolutely higher than having poor attention while studying. Suratch ${ }^{[10]}$ found that casual factors beyond the cognitive one that influence on learning processes of 1,330 Udonthani Rajabhat University seniors attending the 2nd semester of academic year 2003 cited that concentration affected directly to the students' learning achievement

- Attitude toward mathematics took both direct and indirect effect on students' mathematic problem solving by passing through concentration on classes. The reason why the attitude toward the subject had a positive effect on the students' problem solving at 0.05 level of significance was because the pupils had a good attitude on mathematics and realized that it was important to learn so as to apply the knowledge in daily life, then the students loved and enjoyed learning, they also concentrated on their solving problem and they could improve themselves at the result

- Achievement motive was the direct factor influencing students' problem-solving ability by passing through the learners' concentration and their attitude toward mathematics. According to this research, an achievement motive had a positive effect on problem solving of the students at.05 level of significance. This was because the achievement motive was the students' desire to do any thing so as to get a success or to do better than any other people. Therefore, if students have an achievement motive to solve the mathematic problems effectively, they will have a good attitude toward the subject as well; what's more, students will have more concentration and pay attention to the class, then they will have high ability in mathematic problem solving. The research result associated with McClelland ${ }^{[8]}$ which revealed that the students who had an achievement motive would be successful in their study. It also related to the research of Chae-Um ${ }^{[11]}$ on the variables affecting the mathematic problem solving

- Self-esteem was both direct and indirect effect to mathematic problem solving by passing through achievement motive and attitude toward the subject. Self-esteem affected the students' mathematic problem solving ability in a positive way at.01 level of significance. Purkey ${ }^{[12]}$ believed that self-esteem was a basic motivation affecting each student's ability to have different learning achievement from his friends. Any student who had high self-esteem seemed to not be serious while he was going to learn mathematics and he would not feel excited while facing the complicated mathematic problems or even when he was about to take the test. Furthermore, that 
student would concentrate on mathematic learning, he would have a good attitude toward the subject and then he had a high ability to solve mathematic problems

- Self-efficacy took positive indirect effect on the problem solving of students by passing through achievement motive, attitude and concentration at 0.01 level of significance. This was because the students could judge their ability from any problem happening to them. Bandura ${ }^{[13]}$ revealed that selfefficacy paid an important role in thinking ability which was the base of motivation. Any one who had high self-efficacy and goal in his life would have higher achievement motive and attitude in working than one who was wondering about his ability. Moreover, it also encouraged students to concentrate on the lesson; therefore, the students of this research achieved in learning and solving the problems of mathematics. Michai ${ }^{[14]}$ had studied the correlation among some effective domains, mathematical learning and teaching behaviors and problem solving of students. The results of the study indicated that self-efficacy was significantly correlative to the students' problem solving ability at the statistic level of 0.01

Teacher's behavior took both direct and indirect effects on problem solving ability of students by having indirect effect passing through achievement motive and attitude toward the subject. In this study, the teacher's behaviors took positive effect on students' problem solving ability at 0.01 level of significance since the teacher had managed the class with various activities, the educational tools were appropriate for the students, what's more, the teacher knew about the psychology of teaching so as to meet each student's need and the assessment or evaluation of the teacher matched with the objective of the curriculum. The results of this study associated with Anan ${ }^{[15]}$ who had studied about the analysis of casual correlation of the variables influencing 427 students. The result found that the teacher's behavior affected directly to their problem solving abilities. These behaviors encouraged students to be enthusiastic, responsible for their learning, they also had good attitude toward the subject. And when they were engrossed, willing and happy in solving mathematic problems, they would improve themselves

\section{CONCLUSION}

The teachers should develop their teaching techniques, assessment and evaluation to be various and modern and bring the psychology to apply through teaching mathematic activities especially in problem solving since the research results indicated that teacher's behaviors took both direct and indirect effects on the students' mathematic problem solving. The teachers are supposed to study the methods to develop this ability deeply and then bring them to manage the activities in class that encourage students to be enthusiastic to learn and have good attitude toward mathematic learning or to get students' concentration. The students will then have higher ability in mathematic problem solving. Also, Teachers should encourage students to realize self-efficacy, self-esteem and self-respect because these factors help students gain higher achievement motive and if the students have high achievement motive, they will have good attitude toward learning, then they will concentrate on learning and they will be efficiently successful in studying as they expect.

Variables could explain the variance of students' problem solving ability at $63.00 \%$ and the rests of percentage were laid on for other variables. Therefore, to develop factor models affecting mathematic problem solving ability, relevant factors such as students' intellect, reading ability, skills, teacher's experience, teacher's education, classroom environment, student's being creative, parents' fostering and extra time for learning should be studied. The models that were made should be analyzed to fit the surrounding environment by separating into 2 models. The first one is measurement model used for analyzing the factors that present linear relationship between the hidden variable and the visible one. This model can reduce the deviation by applying the assuring component method during the measurement. The second one is structural equation model, a model that identifies the relationship of linear structure between the factors or the hidden variables in the research model. The analysis of these two models causes the relationship between the hypothesis model and the real status and lead to the development of theories or making new knowledge.

\section{ACKNOWLEDGEMENT}

The researchers are sincerely appreciated to Mahasarakham University for financial support.

\section{REFERENCES}

1. Branca, N., 1980. Problem Solving as a Goal, Process and Basic Skill. In: Problem Solving in School Mathematics, Krulik, S. and R.E. Reys (Eds.). National Council of Teachers of Mathematics, Reston, VA., ISBN: 10: 0873531620, pp: 241. 
2. Chapman, O., 1997. Metaphors in the teaching of mathematical problem solving. Educ. Stud. Math., 32: 201-228. DOI: 10.1023/A:1002991718392

3. Schommer-Aikins, M., O.K. Duell and R. Hutter, 2005. Epistemological beliefs, mathematical problem-solving beliefs and academic performance of middle school students. Element. School J., 105: 289-304.

http://www.eric.ed.gov/ERICWebPortal/custom/portl ets/recordDetails/detailmini.jsp?_nfpb=true\&_\&ERIC ExtSearch_SearchValue_0=EJ696847\&ERICExtSear ch_SearchType_0=no\&accno=EJ696847

4. Pajares, F. and J. Kranzler, 1995. Self-efficacy beliefs and general mental ability in mathematical problem-solving. Contemp. Educ. Psychol., 20: 426-443.

http://cat.inist.fr/?aModele $=$ afficheN\&cpsidt $=2896$ 338

5. Pajares, F., 1996. Self-efficacy beliefs and mathematical problem-Solving of gifted students. Contemp. Educ. Psychol., 21: 325-344. PMID: 8979868

6. Lesh, R.A. and H.M. Doerr, 2002. Beyond Constructivism: Models and Modeling Perspectives on Mathematics Problem Solving, Learning and Teaching. Lawrence Erlbaum, New Jersey, USA., ISBN: 10: 0805838228, pp: 616.

7. B.S. Bloom and M.D. Engelhart, 1956. Taxonomy of Educational Objectives: The Classification of Educational Goals: Handbook I: Cognitive Domain. Longmans, New York, USA., ISBN: 058232386X, pp: 207.

8. McClelland, D.C., 1999. The Achieving Society. Princeton. Free Press, New Jersey, Van Nostrand, ISBN: 9780029205105 , pp: 532.

9. Bandura, A., 1977. Social Learning Theory. Englewood Cliffs, New Jersey, USA.
10. Suratch, M., 2004. The causal factors beyond the cognitive influencing on Udonthani Rajabhat University students' learning achievement. M.Ed. Thesis, Mahasarakham University, Mahasarakham, Thailand. Unpublished Document.

11. Chae-um, J., 2007. Factors affecting mathematics problem solving ability of prathomsuksa 4 students in Roi-et educational service area 3. M.Ed. Thesis, Mahasarakham University, Mahasarakham, Thailand. Unpublished Document.

12. Purkey, W.W., 1970. Self Concept and School Achievement. Prentice Hall College Div, New Jersey, USA., ISBN: 10: 0138031630, pp: 86.

13. Bandura, A., 1999. A sociocognitive analysis of substance abuse: an agentic perspective. Psychol. Sci., 10: 214-217. DOI: 10.1111/1467-9280.00138

14. Michai, P., 2005. The relationship of some effective domains, mathematical learning behavior, teaching mathematics and problem solving ability in Yasothon. M.Ed. Thesis, Mahasarakham University, Mahasarakham, Thailand. Unpublished document.

15. Anan, K., 2003. Analysis of causal variables influencing matthayomsuksa 3 students' mathematic problem solving ability. M.Ed. Thesis, Srinakharinwirot University, Bangkok, Thailand. Unpublished Document. 